\title{
Short-Term Stable Isotope Probing of Proteins Reveals Taxa Incorporating Inorganic Carbon in a Hot Spring Microbial Mat
}

\author{
Laurey Steinke, ${ }^{a}$ Gordon W. Slysz, ${ }^{\text {b }}$ Mary S. Lipton, ${ }^{b}$ Christian Klatt, ${ }^{c}$ James J. Moran, ${ }^{b}$ Margie F. Romine, ${ }^{b}$ Jason M. Wood, ${ }^{c *}$ \\ Gordon Anderson, ${ }^{b}$ (D) Donald A. Bryant, ${ }^{\text {d,e David M. Wardc }}$
}

aDepartment of Biochemistry and Molecular Biology, University of Nebraska Medical Center, Omaha, Nebraska, USA

bEnvironmental Molecular Sciences Division, Pacific Northwest National Laboratory, Richland, Washington, USA

'Department of Land Resources and Environmental Sciences, Montana State University, Bozeman, Montana, USA

dDepartment of Biochemistry and Molecular Biology, The Pennsylvania State University, State College, Pennsylvania, USA

eDepartment of Chemistry and Biochemistry, Montana State University, Bozeman, Montana, USA

ABSTRACT The upper green layer of the chlorophototrophic microbial mats associated with the alkaline siliceous hot springs of Yellowstone National Park consists of oxygenic cyanobacteria (Synechococcus spp.), anoxygenic Roseiflexus spp., and several other anoxygenic chlorophototrophs. Synechococcus spp. are believed to be the main fixers of inorganic carbon $\left(C_{i}\right)$, but some evidence suggests that Roseiflexus spp. also contribute to inorganic carbon fixation during low-light, anoxic morning periods. Contributions of other phototrophic taxa have not been investigated. In order to follow the pathway of $C_{i}$ incorporation into different taxa, mat samples were incubated with $\left[{ }^{13} \mathrm{C}\right]$ bicarbonate for $3 \mathrm{~h}$ during the early-morning, low-light anoxic period. Extracted proteins were treated with trypsin and analyzed by mass spectrometry, leading to peptide identifications and peptide isotopic profile signatures containing evidence of ${ }^{13} \mathrm{C}$ label incorporation. A total of 25,483 peptides, corresponding to 7,221 proteins, were identified from spectral features and associated with mat taxa by comparison to metagenomic assembly sequences. A total of 1,417 peptides, derived from 720 proteins, were detectably labeled with ${ }^{13} \mathrm{C}$. Most ${ }^{13} \mathrm{C}$-labeled peptides were derived from proteins of Synechococcus spp. and Roseiflexus spp. Chaperones and proteins of carbohydrate metabolism were most abundantly labeled. Proteins involved in photosynthesis, $C_{i}$ fixation, and $\mathrm{N}_{2}$ fixation were also labeled in Synechococcus spp. Importantly, most proteins of the 3-hydroxypropionate bi-cycle for $C_{i}$ fixation in Roseiflexus spp. were labeled, establishing that members of this taxocene contribute to $C_{i}$ fixation. Other taxa showed much lower $\left[{ }^{13} \mathrm{C}\right]$ bicarbonate incorporation.

IMPORTANCE Yellowstone hot spring mats have been studied as natural models for understanding microbial community ecology and as modern analogs of stromatolites, the earliest community fossils on Earth. Stable-isotope probing of proteins (ProSIP) permitted short-term interrogation of the taxa that are involved in the important process of light-driven $C_{i}$ fixation in this highly active community and will be useful in linking other metabolic processes to mat taxa. Here, evidence is presented that Roseiflexus spp., which use the 3-hydroxypropionate bi-cycle, are active in $C_{i}$ fixation. Because this pathway imparts a lower degree of selection of isotopically heavy $C_{i}$ than does the Calvin-Benson-Bassham cycle, the results suggest a mechanism to explain why the natural abundance of ${ }^{13} \mathrm{C}$ in mat biomass is greater than expected if only the latter pathway were involved. Understanding how mat community members influence the ${ }^{13} \mathrm{C} /{ }^{12} \mathrm{C}$ ratios of mat biomass will help geochemists interpret the ${ }^{13} \mathrm{C} /{ }^{12} \mathrm{C}$ ratios of organic carbon in the fossil record.

KEYWORDS Mushroom Spring, geochemistry, inorganic carbon uptake, metaproteomics, microbial mat, phototrophy, stable isotope probing, stable isotope signature, stromatolite

Citation Steinke L, Slysz GW, Lipton MS, Klatt C Moran JJ, Romine MF, Wood JM, Anderson G, Bryant DA, Ward DM. 2020. Short-term stable isotope probing of proteins reveals taxa incorporating inorganic carbon in a hot spring microbial mat. Appl Environ Microbiol 86:e01829-19. https://doi.org/10.1128/AEM .01829-19.

Editor Robert M. Kelly, North Carolina State University Copyright $\odot 2020$ American Society for Microbiology. All Rights Reserved. Address correspondence to David M. Ward, umbdw@montana.edu.

* Present address: Jason M. Wood, California Institute of Technology, Jet Propulsion Laboratory, Biotechnology and Planetary Protection Group, Pasadena, California, USA Received 10 October 2019 Accepted 12 January 2020 Accepted manuscript posted online 17 January 2020

Published 18 March 2020 
icrobial communities are the primary catalysts of biogeochemical systems on Earth (1), yet relating the taxa comprising a community to the specific metabolic processes they perform is difficult. The recent development of stable-isotope probing (SIP) of proteins (Pro-SIP) has provided an elegant solution to this problem (2-5). In any system with a sufficiently high metabolic rate, compounds labeled with stable isotopes can be incorporated into proteins. In this case, some of the peptides comprising the protein will become labeled and can thus be differentiated by mass spectral shifts during proteomics analysis (5). The amino acid sequence of the labeled peptides can then be associated with taxa through phylogenetic comparisons, and the functions of these proteins can also be inferred. Recent examples of the use of Pro-SIP include (i) identification of toluene-degrading taxa in a constructed wetland model (6), (ii) identification of acetate-oxidizing bacteria in an anaerobic digester (7) and in a benzenemineralizing, sulfate-reducing consortium (8), and (iii) tracking protein synthesis in an anaerobic methane-oxidizing mesocosm derived from a marine methane seep community (9). One distinct advantage of Pro-SIP, which can be a problem with other biomarkers (see below), is that it requires only that some proteins within an organism are being synthesized at the time of the experiment. In the present study, we report on the use of Pro-SIP to determine which taxa participate in photosynthetic bicarbonate fixation in the hot spring microbial mat community of Mushroom Spring, which has been studied as a model for understanding principles of microbial community ecology and as a modern analog of stromatolites, the oldest fossil communities on Earth (10-12).

It was initially thought that unicellular cyanobacteria of the genus Synechococcus were solely responsible for fixation of inorganic carbon $\left(C_{i}\right)$ in this mat system and that their metabolic products were cross-fed to community members, such as the filamentous Chloroflexi (i.e., Chloroflexus and Roseiflexus), which were known to be photoheterotrophic in culture $(10,13,14)$. Support for the inference of photoheterotrophy also came from microautoradiographic evidence of the uptake of ${ }^{14} \mathrm{C}$-labeled fermentation products and glycolate by filamentous community members $(15,16)$. Although one Chloroflexus strain had been shown at the time to be capable of photoautotrophy (17), this activity was thought to be impossible in mats made oxic by oxygenic photosynthesis, such as that performed by Synechococcus. It was thought at the time that anoxygenic photoautotrophy required anoxic conditions and inorganic reductants, such as $\mathrm{H}_{2} \mathrm{~S}$ and $\mathrm{H}_{2}$, which were unlikely to be present under oxic conditions.

Natural abundance data of ${ }^{13} \mathrm{C}$ in lipid biomarkers had suggested, however, that in addition to oxygenic photosynthesis by Synechococcus spp., key anoxygenic phototrophic mat inhabitants, Roseiflexus spp., might also be performing bicarbonate fixation $(18,19)$. The lipid biomarkers of Roseiflexus spp. were observed to be isotopically heavier than those of Synechococcus spp., which was unexpected if Roseiflexus species incorporated Synechococcus species excretion products photoheterotrophically (i.e., you are what you eat). Because Roseiflexus spp. use the 3-hydroxypropionate bi-cycle to incorporate bicarbonate in a photomixotrophic metabolism and because this pathway leads to fixed carbon that is isotopically heavier than the carbon fixed by the Calvin-Benson-Bassham cycle used by Synechococcus spp., this could be a mechanism explaining the observed isotopically heavier Roseiflexus species lipid biomarkers.

We focused on the low-light, early-morning period when the mat is in shadow because of its proximity to a forested hill. Although Synechococcus spp. perform light-limited, oxygenic photosynthesis at this time, the low rate of oxygen evolution is completely offset by the rate of oxygen consumption due to aerobic respiration. Thus, the mat remains anoxic, and reductants $\left(\mathrm{H}_{2}\right.$ and $\left.\mathrm{H}_{2} \mathrm{~S}\right)$ are still available for an extended period of time after sunrise (20). Initially, we based inferences on methods that do not directly link functions with the taxa performing them. For instance, we reported that light-stimulated $\left[{ }^{14} \mathrm{C}\right]$ bicarbonate fixation into mat biomass during the low-light period occurs in the presence of either visible or infrared light and that incorporation could be stimulated by addition of $\mathrm{H}_{2}$ and $\mathrm{H}_{2} \mathrm{~S}$ (20). Seeking a stronger link between function and taxa, we studied SIP labeling of lipid biomarkers in Synechococcus spp. and Roseiflexus 
TABLE 1 Number of mass spectral features, peptides, proteins, and ${ }^{13} \mathrm{C}$-labeled peptides and proteins that are unique to taxa and their associated proteins

\begin{tabular}{llllll}
\hline & $\begin{array}{l}\text { No. of mass } \\
\text { spectral } \\
\text { features }\end{array}$ & $\begin{array}{l}\text { No. of } \\
\text { peptides }\end{array}$ & $\begin{array}{l}\text { No. of } \\
\text { proteins }\end{array}$ & $\begin{array}{l}\text { No. of } \\
\text { peptides } \\
\text { labeled }\end{array}$ & $\begin{array}{l}\text { No. of } \\
\text { proteins } \\
\text { labeled }\end{array}$ \\
Taxon & 48,703 & 9,070 & 1,865 & 426 & 137 \\
\hline Roseiflexus & 39,184 & 3,674 & 1,322 & 177 & 59 \\
Synechococcus & 2,641 & 654 & 271 & 29 & 18 \\
"Ca. Thermochlorobacter" & 2,441 & 501 & 174 & 4 & 3 \\
"Ca. Roseilinea" & 817 & 148 & 73 & 2 & 3 \\
Chloracidobacterium & 523 & 128 & 67 & 2 & 2 \\
Armatimonadetes & 381 & 123 & 63 & 1 & 1 \\
Pseudothermotoga & 1,026 & 104 & 34 & 5 & 4 \\
Chloroflexus & 1,145 & 273 & 212 & 2 & 2 \\
Unknown & 5,942 & 1,118 & 844 & 13 & 13 \\
Other & & & & & 242 \\
Total & 102,803 & 15,793 & 4,925 & 661 & \\
\hline
\end{tabular}

spp. and concluded that both appear to fix bicarbonate at this time of day (20). We subsequently confirmed early-morning incorporation of $\left[{ }^{13} \mathrm{C}\right]$ bicarbonate into biomass fractions derived from Percoll gradient centrifugation that contained predominantly either Synechococcus spp. or Roseiflexus spp. (21). However, these approaches may have suffered from the presence of unknown community members with the potential to fix bicarbonate, which might have copurified with more abundant organisms in the Percoll fractions analyzed. Indeed, more recent comprehensive analyses of the major taxa (also called taxocenes, as these are groups containing many species united by their phylogenetic similarity) inhabiting the upper 1 to $2 \mathrm{~mm}$ of the photic zone of this mat based on metagenomic assembly clusters $(22,23), 16 \mathrm{~S}$ rRNA iTag sequences (24), and cultivation methods $(25,26)$ have reinforced these concerns. As listed in Table 1 , the mat community contains not only oxygenic photosynthetic cyanobacteria (Synechococcus spp.) and anoxygenic Roseiflexus spp. (22) but also other filamentous Chloroflexi (Chloroflexus spp. and "Candidatus Roseilinea gracile") and two other aerobic/microaerophilic, anoxygenic chlorophototrophs, Chloracidobacterium thermophilum (25, 27-30) and "Candidatus Thermochlorobacter aerophilum" $(25,31)$, which may be capable of light-dependent bicarbonate assimilation $(26,28-30,32)$. Because of the potential of Pro-SIP to relate incorporated ${ }^{13} \mathrm{C}$ with identifiable proteins derived from all of these mat taxa, we applied this technique to revisit the question of which taxa incorporate ${ }^{13} C_{i}$ in this system.

\section{RESULTS}

A $\left[{ }^{13} \mathrm{C}\right]$ bicarbonate uptake experiment was conducted on mat samples obtained from and incubated at a $60^{\circ} \mathrm{C}$ site in Mushroom Spring between 0600 and $0900 \mathrm{~h}$ when the system was in shade. The initial downwelling irradiance was $16.69 \mu \mathrm{mol}$ photons $\mathrm{m}^{-2} \mathrm{~s}^{-1}$, and this value increased to $157.39 \mu \mathrm{mol}$ photons $\mathrm{m}^{-2} \mathrm{~s}^{-1}$ by 0657 and remained near this level until the end of the incubation period. Proteins extracted from these samples after incubation were analyzed by liquid chromatography-tandem mass spectrometry (LC-MS/MS).

The Mushroom Spring early-morning metaproteome. Interrogation of an assembled, translated, and annotated metagenome of Mushroom/Octopus Springs (22) with the collected mass spectral data led to the identification of 25,483 peptides (the full data set is provided in Data Set S1 in the supplemental material), which were derived from 7,221 identified proteins (Data Set S2). Because we were able to associate the annotated proteins with metagenomic sequence assemblies for each of the major taxa inhabiting the mat, each identified protein could further be associated with one of the predominant mat inhabitants. However, because some conserved peptides are shared by members of more than one taxocene, we used a "unique-to-taxon" subset of peptides for all quantitation (Fig. 1A). Calculations performed to determine either the number of identified peptides or the number of mass spectral features associated with 


\section{A Taxa Identified by Sum of Different Peptides}

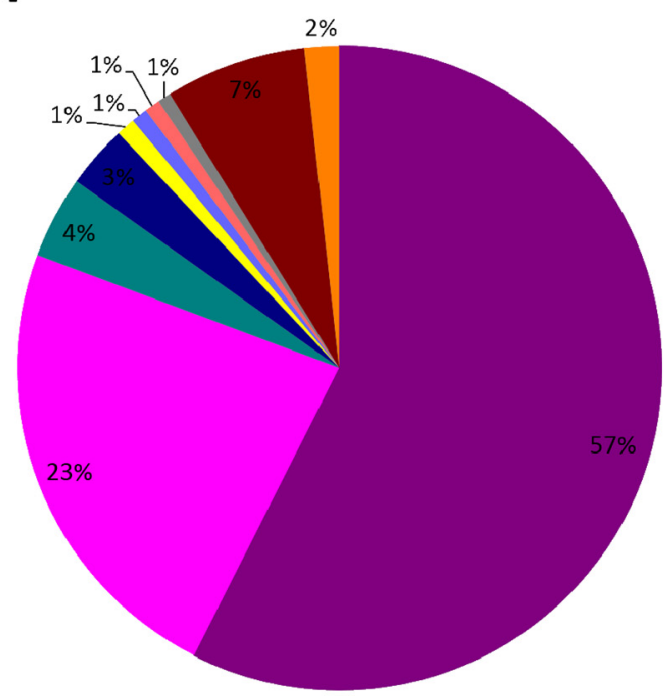

- Roseiflexus

- Synechococcus

- "Ca. Thermochlorobacter"

- "Ca. Roseilinea"

Armatimonadetes

- Pseudothermotoga

- Chloracidobacterium

- Chloroflexus

- Other

Unknown

B

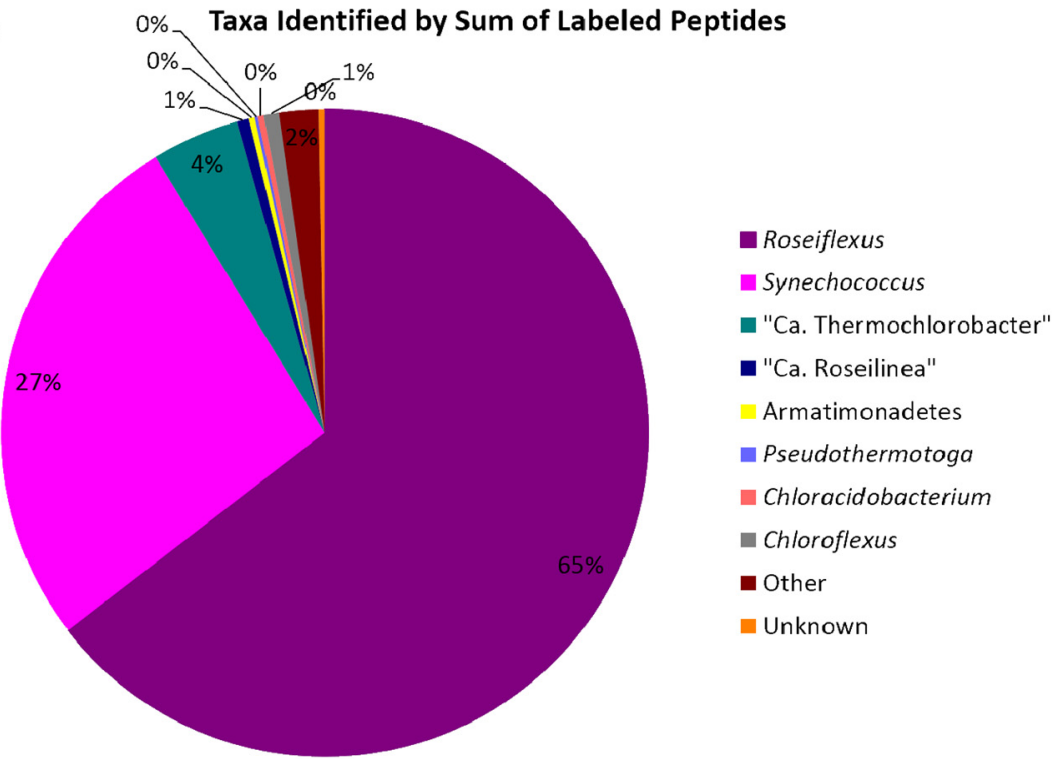

FIG 1 Contributions of major mat taxa to the Mushroom Spring metaproteome (A) and to ${ }^{13}$ C-labeled peptides (B) based on peptides unique to taxa.

specific taxa produced very similar results (Table 1). The predominant peptides of the proteome were those associated with members of the genera Synechococcus and Roseiflexus. Peptides associated with "Ca. Thermochlorobacter," Chloracidobacterium, "Ca. Roseilinea," Chloroflexus, Armatimonadetes, and Pseudothermotoga (23) were detected significantly less frequently. Organisms belonging to the genus Roseiflexus contributed the most peptides (57\%) to the metaproteome, followed by Synechococcus (23\%), "Ca. Thermochlorobacter" (4\%), and "Ca. Roseilinea" (3\%). Organisms belonging to the genera Chloracidobacterium, Chloroflexus, and Pseudothermotoga and members of the Armatimonadetes each contributed fewer than $1 \%$ of the identified peptides. The relative contributions of each of these taxa to the overall community are comparable to their estimated contributions from the metagenome, rRNA sequences derived from metatranscriptome sequencing, or iTag analyses (Table 2). Furthermore, very similar results were reported for the midday Octopus Spring $60^{\circ} \mathrm{C}$ mat metaproteome (33). The functions associated with the proteins detected in the early-morning metaproteome from Mushroom Spring (Fig. 2A) were also similar to those detected in the Octopus 
TABLE 2 Contribution by mat taxa to the Mushroom Spring metaproteome, the metagenome, the metatranscriptome, and ${ }^{13} \mathrm{C}$-labeled peptides

\begin{tabular}{|c|c|c|c|c|c|c|c|}
\hline \multirow[b]{2}{*}{ Taxon } & \multicolumn{6}{|c|}{ Taxon contribution (\%) by: } & \multirow[b]{2}{*}{$\begin{array}{l}\% \text { labeled peptides } \\
\text { associated with taxa }\end{array}$} \\
\hline & $\begin{array}{l}\text { MS } \\
\text { features }\end{array}$ & Peptide & $\begin{array}{l}\text { Metagenome } \\
\text { recruitment }^{a}\end{array}$ & $\begin{array}{l}16 S \text { rRNA } \\
\text { amplicon }^{b}\end{array}$ & $\begin{array}{l}16 \mathrm{~S} \text { rRNA in } \\
\text { metatranscriptome }\end{array}$ & $\begin{array}{l}\text { mRNA in } \\
\text { metatranscriptome }\end{array}$ & \\
\hline Roseiflexus & 47.4 & 57.4 & 16.0 & 33.9 & 41.0 & 42.0 & 5.1 \\
\hline Synechococcus & 38.5 & 23.3 & 29.8 & 37.4 & 21.0 & 21.0 & 6.1 \\
\hline "Ca. Thermochlorobacter" & 2.7 & 4.1 & 6.5 & 2.2 & 13.0 & 8.0 & 4.6 \\
\hline "Ca. Roseilinea" & 2.3 & 3.2 & 0.8 & 1.2 & & & 0.6 \\
\hline Chloracidobacterium & 0.8 & 0.8 & 9.7 & 5.2 & 6.0 & 3.0 & 2.0 \\
\hline Armatimonadetes & 0.5 & 0.9 & 7.0 & 0.8 & & & 1.3 \\
\hline Pseudothermotoga & 0.4 & 0.8 & 8.1 & & & & 0.8 \\
\hline Chloroflexus & 1.0 & 0.7 & 9.4 & 1.2 & & & 4.6 \\
\hline
\end{tabular}

a From reference 22 .

${ }^{b}$ From reference 23 . The absence of a numerical value indicates that no values were presented for these taxa.

cFrom reference 34 . The absence of a numerical value indicates that no values were presented for these taxa; the value for Roseiflexus was actually reported as that for Chloroflexi and would have also included Chloroflexus.

Spring midday metaproteome. Notable exceptions were $\mathrm{N}_{2}$ fixation and fermentation proteins from Synechococcus, which were detected only in the early-morning metaproteome from Mushroom Spring.

Labeled peptides. Protein extracts were analyzed by isotope ratio mass spectrometry to determine the extent of enrichment in ${ }^{13} \mathrm{C}$ during the incubation period. Pooled unlabeled samples (i.e., incubated with $\left[{ }^{12} \mathrm{C}\right]$ bicarbonate) showed a bulk isotopic composition of $-15.0 \%$ ( $\pm 0.02 \%$ o standard deviation), typical for hot spring cyanobacterial mats $(18,19)$. However, pooled ${ }^{13} \mathrm{C}$-labeled samples were heavily enriched $(+221 \%$ o $\pm 3 \%$ o). In LC-MS/MS analysis of the peptide spectra obtained from samples incubated with ${ }^{12} \mathrm{CO}_{2}$, only the typical isotopic distribution pattern of masses was observed, with four or five peaks in the isotopic envelope (Fig. 3A and B). However, after incorporation of ${ }^{13} \mathrm{C}$, the number of ions observed in the isotopic envelope increased, and the envelope developed a "tail" of ions of higher mass (Fig. 3, compare A and B to $C$ and $D$, respectively). This change was due to the incorporation of ${ }^{13} \mathrm{C}$ into the protein; the amount incorporated was sufficient to change the isotopic ratio but small enough to not dramatically change the overall character of the mass spectrum of the peptide. Automated analysis of trypsin-digested proteins in samples using SIPPER (see Materials and Methods) detected ${ }^{13} \mathrm{C}$ labeling of 1,417 peptides that were derived from 720 proteins (Data Sets S1 and S2). Thus, 5.6\% of the total identified peptides were detectably labeled with ${ }^{13} \mathrm{C}$. As shown in Fig. 1B (and Table 1), ${ }^{13} \mathrm{C}$ labeling of peptides that were unique to taxa was predominantly associated with Roseiflexus spp. and Synechococcus spp. and, to a much lower degree, with peptides and proteins of " $\mathrm{Ca}$. Thermochlorobacter," Chloroflexus, and other mat taxocenes (Table 1).

The labeled proteins presumably included constitutively produced proteins and those proteins that are specifically synthesized during this early-morning, low-light period. The functions associated with labeled peptides resembled those of proteins without labeled peptides, with the notable exception of proteins associated with protein folding (compare Fig. 2A and B). Members of this functional category were labeled to a disproportionately high degree compared to labeling of proteins of other functional classes (Fig. 2B).

Functional analysis of labeled proteins observed within taxocenes. Because members of Synechococcus and Roseiflexus were most heavily labeled, here we restrict detailed consideration to the results for these two taxa. The extent of labeling in proteins of various functional classes is summarized in Table 3, and the reader is referred to supplemental Data Set S2 for a listing of all labeled proteins identified.

(i) Synechococcus spp. The most heavily labeled Synechococcus species peptides were associated with transcription, protein synthesis, and protein folding, and these comprised half of the total labeled peptides detected from Synechococcus spp. Proteins associated with carbohydrate metabolism (e.g., enzymes involved in glycolysis and 


\title{
A Number of Distinct Peptides per Function
}

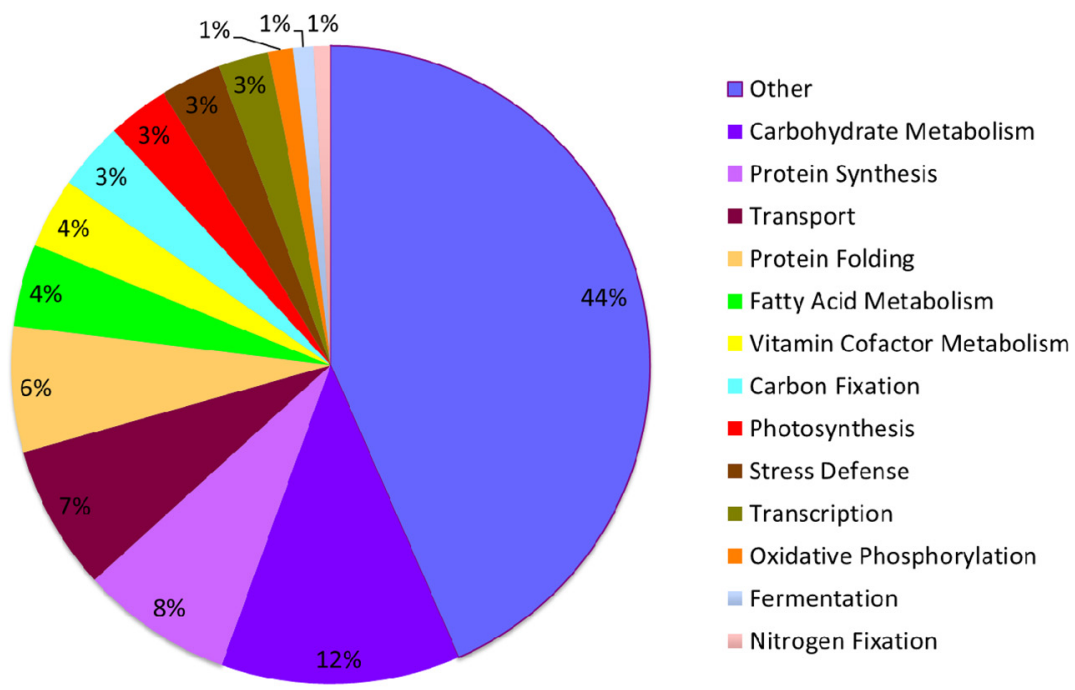

B Number of Labeled Peptides per Function

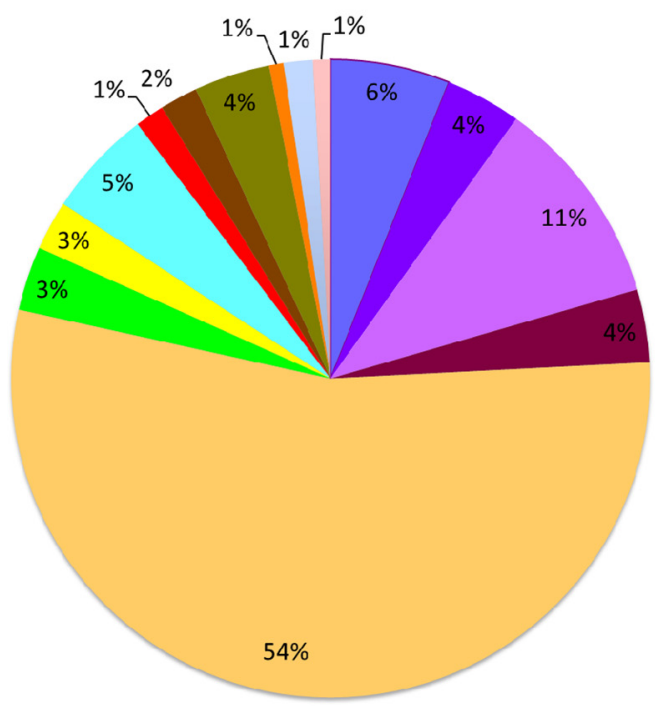

\author{
口Other \\ - Carbohydrate Metabolism \\ Protein Synthesis \\ - Transport \\ Protein Folding \\ - Fatty Acid Metabolism \\ Vitamin Cofactor Metabolism \\ Carbon Fixation \\ - Photosynthesis \\ Stress Defense \\ - Transcription \\ - Oxidative Phosphorylation \\ Fermentation \\ Nitrogen Fixation
}

FIG 2 Functions determined by number of peptides unique to taxa in the Mushroom Spring metaproteome $(\mathrm{A})$ and ${ }^{13} \mathrm{C}$-labeled peptides (B).

glycogen metabolism), photosynthesis (e.g., photosystems I and II, phycocyanin and allophycocyanin, and other phycobilisome components), carbon fixation (e.g., ribulose bisphosphate carboxylase subunits and carbon concentrating mechanism proteins), and nitrogen fixation (e.g., a nitrogenase subunit) were also labeled significantly, together accounting for nearly $16 \%$ of the labeled Synechococcus species proteins identified. The most heavily labeled of these were proteins associated with the CalvinBenson-Bassham cycle and carbon-concentrating mechanisms, with three different labeled proteins detected, two of which were detected with six to eight different labeled peptides (Table 4). Seven different proteins associated with the light-harvesting apparatus were detected, two of which were detected with two different labeled peptides (Table 4). Two labeled peptides associated with a nitrogen fixation protein were detected (Table 4).

(ii) Roseiflexus spp. As shown in Table 3 and similar to the results for Synechococcus spp. described above, the most heavily labeled Roseiflexus species peptides were those associated with transcription, protein synthesis, and protein folding, comprising about 

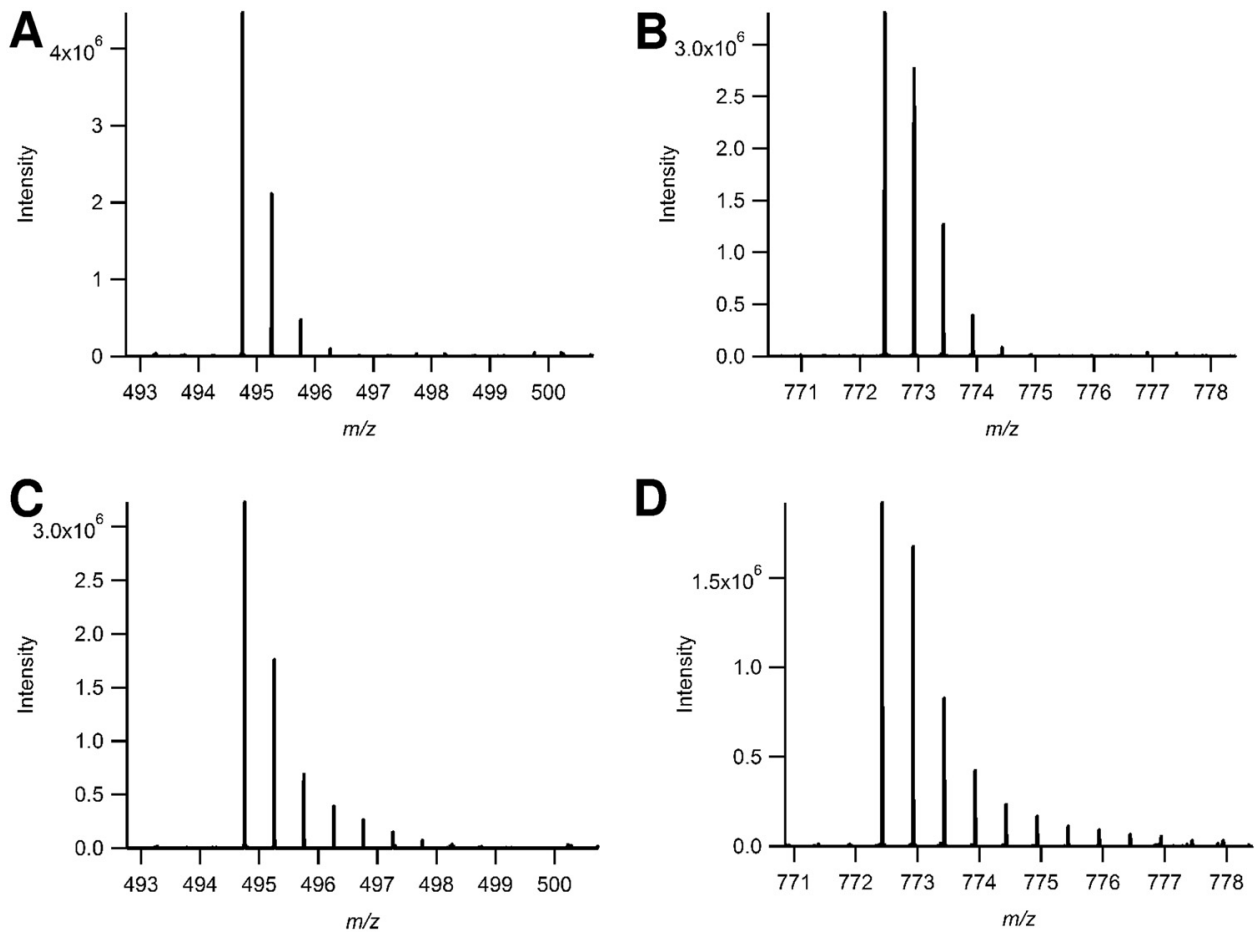

FIG 3 Representative mass spectra showing the tailing effect of the mass envelope observed when ${ }^{13} \mathrm{C}$ is incorporated into peptides. Panels $A$ and $C$ show the mass envelopes for peptide mass identification number 17551702 , a peptide derived from chaperonin GroEL, Roseiflexus sp. RS-1 ( $\mathrm{m} / \mathrm{z} 495)$. Panels B and D show the mass envelopes for peptide mass identification number 237519566: TCP-1/Cpn60 chaperonin family, Synechococcus sp. JA-2-3B' $\mathrm{A}(2-13)(\mathrm{m} / \mathrm{z} 773)$. Panels $\mathrm{A}$ and $\mathrm{B}$ show mass evelopes for peptides derived from the samples incubated with $\mathrm{H}^{12} \mathrm{CO}_{3}{ }^{-}$while panels $\mathrm{C}$ and $\mathrm{D}$ show the extended isotopic envelopes that result from the incorporation of $\mathrm{H}^{13} \mathrm{CO}_{3}^{-}$.

$45 \%$ of the labeled peptides detected for Roseiflexus spp. This result suggests that the early-morning, low-light period is a time of biosynthesis and growth for these organisms. Peptides associated with carbohydrate metabolism, carbon fixation (e.g., enzymes of the 3-hydroxypropionate pathway), fatty acid metabolism (e.g., synthases, reductases, and acyl carrier protein), and vitamin cofactor metabolism were also significantly labeled, accounting collectively for $\sim 18 \%$ of the total labeled Roseiflexus species peptides detected. Considering the hypothesis that Roseiflexus spp. fix bicarbonate under the low-light conditions of the shaded, early-morning, anoxic mat, it is worth noting that the evidence for labeling of proteins in the 3-hydroxypropionate pathway is especially strong. Eight different proteins in this pathway/process were labeled, four of which were detected by labeling of two to four different peptides (Table 5).

\section{DISCUSSION}

The high biomass availability and activity of the Mushroom Spring microbial mat enabled the use of Pro-SIP to relate a specific activity of central importance to the community, i.e., uptake and incorporation of ${ }^{13} \mathrm{C}$-labeled bicarbonate, to the taxa conducting this activity in short-term incubations even under the relatively low light energy conditions of early morning. At this time of day transcription is far from maximum, which occurs near midday $(31,34)$. The opportunity to view short-term ${ }^{13} \mathrm{C}$-labeled substrate utilization patterns in a microbial community using Pro-SIP was similar to earlier radiotracer work using ${ }^{14} \mathrm{C}$-labeled compounds. However, in those cases, association with taxa required detailed postlabeling work, such as fluorescence in situ hybridization probing and microautoradiography (see, e.g., reference 35), which targets specific taxa but not all taxa. Using Pro-SIP, we were able to associate the activity in question, uptake and incorporation of $\left[{ }^{13} \mathrm{C}\right]$ bicarbonate, with both Synechococcus spp. and Roseiflexus spp., directly confirming earlier inferences based on SIP of 
TABLE 3 Functional classes of labeled proteins for Synechococcus and Roseiflexus

\begin{tabular}{|c|c|c|c|c|c|c|}
\hline \multirow[b]{2}{*}{ Function(s) } & \multicolumn{3}{|c|}{ Synechococcus profile (no.) } & \multicolumn{3}{|c|}{ Roseiflexus profile (no.) } \\
\hline & $\begin{array}{l}\text { Peptides unique } \\
\text { to taxa }\end{array}$ & $\begin{array}{l}\text { Labeled } \\
\text { proteins }\end{array}$ & $\begin{array}{l}\text { Labeled } \\
\text { peptides }\end{array}$ & $\begin{array}{l}\text { Peptides unique } \\
\text { to taxa }\end{array}$ & $\begin{array}{l}\text { Labeled } \\
\text { proteins }\end{array}$ & $\begin{array}{l}\text { Labeled } \\
\text { peptides }\end{array}$ \\
\hline Amino acid metabolism & 148 & 1 & 3 & 514 & 6 & 10 \\
\hline Carbon fixation & 56 & 3 & 10 & 449 & 11 & 25 \\
\hline Cell division & 24 & 2 & 2 & 30 & 2 & 6 \\
\hline Cell wall synthesis & 14 & 0 & 0 & 42 & 1 & 1 \\
\hline Electron carrier & 56 & 1 & 2 & 105 & 1 & 1 \\
\hline Fatty acid metabolism & 29 & 0 & 0 & 547 & 12 & 21 \\
\hline Fermentation & 40 & 1 & 1 & 109 & 2 & 9 \\
\hline Metabolic process & 40 & 1 & 1 & 196 & 1 & 2 \\
\hline Nitrogen fixation & 65 & 2 & 4 & 55 & 1 & 1 \\
\hline Nitrogen metabolism & 20 & 0 & 0 & 20 & 1 & 1 \\
\hline Porphyrin and chlorophyll metabolism & 29 & 0 & 0 & 171 & 2 & 2 \\
\hline Protein folding & 286 & 6 & 63 & 399 & 11 & 125 \\
\hline Protein synthesis & 318 & 9 & 21 & 664 & 15 & 46 \\
\hline Proteolysis & 134 & 1 & 1 & 163 & 3 & 3 \\
\hline Signal transduction & 81 & 2 & 3 & 277 & 5 & 11 \\
\hline Stress defense & 176 & 2 & 3 & 188 & 5 & 10 \\
\hline Structure & 42 & 1 & 2 & 11 & 0 & 0 \\
\hline Survival & 1 & 0 & 0 & 17 & 1 & 2 \\
\hline Transcription & 89 & 2 & 8 & 263 & 7 & 21 \\
\hline Transport & 395 & 4 & 10 & 508 & 7 & 13 \\
\hline Unknown & 604 & 4 & 18 & 1,963 & 11 & 69 \\
\hline Vitamin cofactor metabolism & 139 & 2 & 2 & 365 & 10 & 14 \\
\hline
\end{tabular}

lipid biomarkers unique to these community members (20). The evidence came from not only the labeling of peptides associated with these taxa but also the labeling of multiple unique peptides from numerous proteins associated with the Calvin-BensonBassham cycle and the 3-hydroxypropionate bi-cycle that must be present if Synechococcus and Roseiflexus taxocenes perform these activities, respectively.

Importantly, Pro-SIP allowed us to ascertain that other taxa with the potential to fix bicarbonate incorporated much less labeled bicarbonate, suggesting that they do not strongly contribute to bicarbonate fixation in the mat during this early-morning time

TABLE 4 List of ${ }^{13} \mathrm{C}$-labeled proteins associated with Synechococcus species light-harvesting apparatus, carbon uptake and fixation, and nitrogen fixation

\begin{tabular}{ll}
\hline Function and common name & No. of labeled peptides unique to taxa \\
\hline Light harvesting & 2 \\
Photosystem I reaction center subunit IV PsaE & 2 \\
Photosystem I reaction center subunit II PsaD & 1 \\
Phycobilisome rod-core linker polypeptide Cpcg1 & 1 \\
Photosystem I reaction center subunit III PsaF & 1 \\
Allophycocyanin, beta subunit ApcB & 1 \\
Allophycocyanin, alpha subunit ApcA & 1 \\
Phycocyanin beta subunit CpcB & 1 \\
Carbon uptake and fixation & 8 \\
Fructose-bisphosphate aldolase, class II, Calvin cycle subtype; fructose-bisphosphate aldolase & 1 \\
Carbon dioxide concentrating mechanism protein CcmK & 1 \\
Carboxysome major structural protein CcmK1 & 1 \\
Nitrogen fixation & 3 \\
Nitrogenase component I, alpha chain; nitrogenase NifD & 3 \\
NifH & 3 \\
\hline
\end{tabular}


TABLE 5 List of ${ }^{13} \mathrm{C}$-labeled proteins associated with the Roseiflexus species 3-hydroxypropionate pathway

\begin{tabular}{lc}
\hline Common name $^{a}$ & No. of labeled peptides unique to taxa \\
\hline Polyfunctional acrylyl-CoA reductase (NADPH), 3-hydroxypropionyl-CoA dehydratase, & 4 \\
3-hydroxypropionyl-CoA synthetase, Pcs & 4 \\
Bifunctional malonyl-CoA reductase, 3-hydroxypropionate dehydrogenase (NADP+) Mcr & 2 \\
Acetyl-CoA carboxyl transferase alpha chain (EC 6.4.1.2), acetyl-CoA carboxyl transferase & 2 \\
beta chain (EC 6.4.1.2), propionyl-CoA carboxylase beta chain (EC 6.4.1.3) & 1 \\
Mesaconyl-C4-CoA hydratase, Meh & 1 \\
Acetyl-CoA carboxylase biotin carboxylase subunit, AccC & 1 \\
Succinyl-CoA:L-malate CoA transferase subunit B, SmtB & 1 \\
Methylmalonyl-CoA epimerase, MceE & 1 \\
Succinate dehydrogenase and fumarate reductase iron-sulfur protein &
\end{tabular}

${ }^{a}$ CoA, coenzyme A.

period. As shown in Table 2, the percentages of "Ca. Thermochlorobacter" and Chloroflexus peptides that were labeled were similar to those of Synechococcus and Roseiflexus spp., but these populations are in very low relative abundance in the mat at this temperature. The percentages of peptides of other low-abundance taxa were labeled to a proportionately lower degree. Thus, it is likely that these taxa serve as internal controls for the possible transfer of fixed $C$ from primary producers to secondary consumers, which was obviously not very large during the short 3-h period investigated. Additional evidence suggesting that it would be difficult to explain the heavy labeling of Roseiflexus as resulting from cross-feeding from Synechococcus spp. was the large amount of $\left[{ }^{14} \mathrm{C}\right]$ bicarbonate incorporation during the early-morning, anoxic period that was observed to occur in the presence of infrared light and the absence of visible light used by Synechococcus spp. (20).

The enhanced labeling of peptides associated with protein folding raises the question of why some proteins become more heavily labeled than others or, alternatively, why the labeled peptides of some proteins are more readily detected than labeled peptides of other proteins. As light energy becomes available to the mat community, transcription increases dramatically (31). One possibility is that these proteins are needed for intense protein production at this time. Another is that these are large water-soluble proteins whose greater numbers of peptides offer more chance of label being detected. Additionally, we know nothing of how rapidly these proteins are turned over relative to turnover of other proteins, and rapid turnover would likely increase the rate of replacement of ${ }^{12} \mathrm{C}$ by ${ }^{13} \mathrm{C}$ atoms.

The early-morning metaproteome for the Mushroom Spring mat compares well with the metaproteome previously described from the midday Octopus Spring mat at a comparable temperature (33). The exception of nitrogen fixation and fermentation enzymes, which were detected only in the early-morning Mushroom Spring mat, is likely correlated with differences in proteins present (or absent) at different times of day. Nitrogen fixation specifically occurs during low-light, anoxic periods in both mats near dawn (and dusk), and nitrogenase is inactivated and presumably is proteolytically degraded when $\mathrm{O}_{2}$ levels rise as sunlight increases and as the rate of oxygenic photosynthesis exceeds the rate of aerobic respiration $(36,37)$. It will be interesting to determine if changes in protein labeling associated with other specific and different functions can be observed during the diel cycle, especially as large differences in transcription over a diel cycle are evident $(31,34,38)$. For instance, the absence of labeled peptides associated with the Roseiflexus species light-harvesting apparatus in the early-morning proteome is consistent with diel transcriptome data that have shown that transcript levels for most genes encoding components of the photosynthetic apparatus are highest during the night, which is when one would expect these proteins to be made (38). Another intriguing transcriptional pattern has led to the suggestion that Roseiflexus spp. may contribute to bicarbonate fixation throughout the day through photomixotrophic use of the 3-hydroxypropionate bi-cycle (38). Interestingly, the lower degree of labeling of Roseiflexus-specific wax ester biomarkers during the afternoon was the basis for previously inferring that this process did not occur (20). 


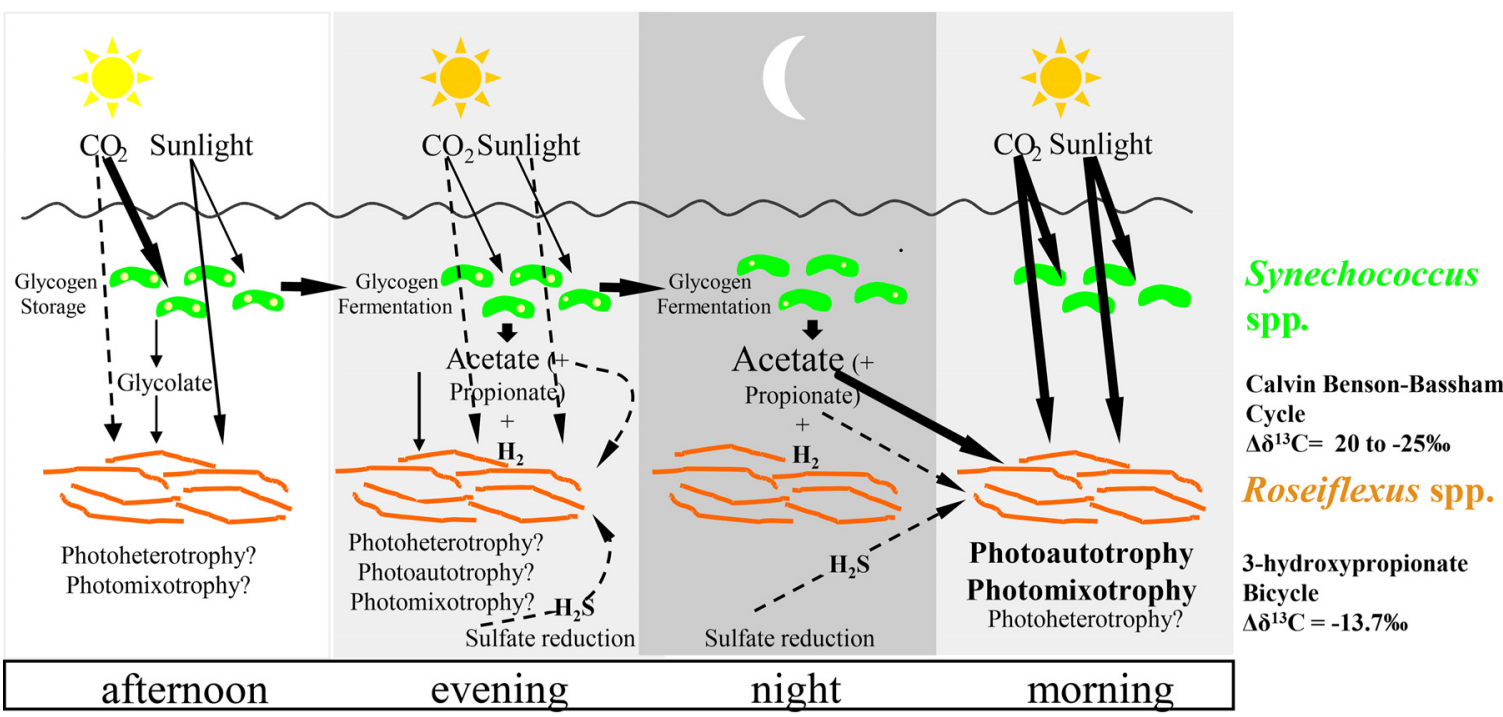

FIG 4 Model of inorganic carbon flow to predominant phototrophic taxa, Synechococcus spp. and Roseiflexus spp., of the Mushroom Spring mat at $60^{\circ} \mathrm{C}$ based on ${ }^{13} \mathrm{C}$ labeling and natural abundance studies. Bold arrows and text indicate the fluxes and metabolisms supported by the data presented in this and previous studies. Question marks indicate photic metabolisms that are suspected or hypothesized, as described in the main text.

However, the labeling experiment in that study was done just before the transcription of wax ester synthase begins in the evening (38). The low degree of $\left[{ }^{13} \mathrm{C}\right]$ bicarbonate incorporation into Roseiflexus species biomarkers may thus have been a consequence of wax esters not being synthesized in the afternoon. Hence, application of Pro-SIP should provide a more direct way of testing this hypothesis, and these experiments are in progress.

Figure 4 shows a modified version of a model we presented originally in van der Meer et al. (20). It has been updated to highlight subsequent studies that have sharpened our view of (i) the use of $C_{i}$ by different phototrophic taxa in the mat and (ii) how this is likely to affect the carbon isotope signature of the mat. The earlier model was based on three main observations. First, Nold and Ward (39) showed that glycogen was the major product of daytime, light-driven uptake of bicarbonate and that stored glycogen was fermented to acetate and propionate in darkness. van der Meer et al. (21) confirmed the diel cycling of glycogen and showed further that this occurred in both Synechococcus- and Roseiflexus-enriched populations, and Kim et al. (40) confirmed the nighttime accumulation and daytime uptake of these fermentation products. Second, van der Meer et al. (20) demonstrated the incorporation of $\left[{ }^{13} \mathrm{C}\right]$ bicarbonate into lipids of what we then called green nonsulfur-like bacteria (now known to be Roseiflexus spp.) in the anoxic mat in early morning. Third, van der Meer et al. (20) also provided evidence for $\mathrm{H}_{2}$ and $\mathrm{H}_{2} \mathrm{~S}$ accumulation during sunset and sunrise, which could provide reductants for photoautotrophy by Roseiflexus spp. The diel cycling of $\mathrm{H}_{2} \mathrm{~S}$ and $\mathrm{H}_{2}$ in the mat have subsequently been further documented by Dillon et al. (41) and Revsbech et al. (42), respectively. Roseiflexus spp. were thought at that time to conduct photoheterotrophic metabolism during the day, using light energy to incorporate glycolate and products of nighttime glycogen fermentation.

The updated model demonstrates what we have learned more recently about the metabolisms of major mat phototrophic inhabitants and mechanisms by which they can influence the stable isotopic signature of mat biomass. First, van der Meer et al. (21) showed that Synechococcus species glycogen is isotopically heavy. Thus, nighttime fermentation of glycogen and cross-feeding of fermentation products the next morning might indirectly contribute to isotopically heavier Roseiflexus cell components (Fig. 4, bold arrows spanning afternoon to morning). Second, the present study established that Roseiflexus spp. fix $C_{i}$ in the anoxic morning mat (Fig. 4, bold arrows in the morning 
panel). This is important because it suggests that the 3-hydroxypropionate pathway used by these organisms can directly influence the stable carbon isotope signature of the mat.

These observations help us understand why the natural abundances of ${ }^{13} \mathrm{C}$ in Octopus Spring and Mushroom Spring mat biomasses are shifted from what would be expected for systems in which photoautotrophy is dominated by Synechococcus spp., which use the Calvin-Benson-Bassham cycle for $C_{i}$ fixation (43). An isotopic fractionation between $C_{i}$ and cellular organic matter of -20 to $-25 \%$ is usually associated with this cycle, but the $\delta^{13} \mathrm{C}$ signatures of mat biomass are -13.2 to $-16.9 \%$, and $\delta^{13} \mathrm{C}$ differences between mat organic matter and endogenous $C_{i}$ (apparent $\Delta \delta^{13} \mathrm{C}$ ) are -6.4 to $-10.1 \%$ o $(18,19)$. It has been known for some time that some Chloroflexus strains could be grown photoautotrophically by making use of the 3-hydroxypropionate bi-cycle (43), which imparts a lower degree of isotopic fractionation between $C_{i}$ and cellular organic matter than the Calvin-Benson-Bassham cycle $(-13.7 \%$ o) $(17,44)$. However, our early models of the metabolisms of Chloroflexi (initially Chloroflexus and later, after 16S rRNA analyses, also Roseiflexus) were biased by fact that these organisms seemed to grow better photoheterotrophically in laboratory culture. The observations we present here indicate that Roseiflexus spp. can directly incorporate $C_{i}$ by the 3-hydroxypropionate bi-cycle, thus directly leading to the production of isotopically heavier mat biomass. If Roseiflexus spp. are found to use this pathway to fix $C_{i}$ throughout the day, as suggested by the diel transcription patterns (38), photoautotrophy (or photomixotrophy) by these organisms could also be an important part of the explanation of why the isotopic signature of the mat biomass is so heavy.

\section{MATERIALS AND METHODS}

Field site. Samples were collected from Mushroom Spring, Yellowstone National Park, WY (latitude 44.5387 , longitude 110.798). The temperature of the source pool fluctuated from 66.4 to $67.1^{\circ} \mathrm{C}$ when measured at 1830 on 18 June 2009.

${ }^{12} \mathrm{C}$ - and ${ }^{13} \mathrm{C}$-labeled incubation solutions. Stock solutions of $58 \mathrm{mM} \mathrm{NaH}{ }^{13} \mathrm{CO}_{3}(99 \%$; Cambridge Isotope Laboratory, Andover, $\mathrm{MA})$ and $\mathrm{NaH}^{12} \mathrm{CO}_{3}$ in anoxic double-distilled $\mathrm{H}_{2} \mathrm{O}\left(\mathrm{dd} \mathrm{H}_{2} \mathrm{O}\right)$ were prepared in advance. On site, unfiltered spring water was acidified to $<\mathrm{pH} 5$ with $0.1 \mathrm{~N} \mathrm{HCl}$ and sparged with nitrogen gas to remove dissolved bicarbonate and oxygen. The stock solutions of bicarbonate were used to restore the spring water to a $\mathrm{pH}$ of 7 to 7.5 , which is within the normal range for this mat (45), and thus produced incubation solutions for which the natural bicarbonate was replaced with either $\mathrm{NaH}^{13} \mathrm{CO}_{3}$ or $\mathrm{NaH}^{12} \mathrm{CO}_{3}$. These solutions were maintained at approximately $55^{\circ} \mathrm{C}$ until use.

Sampling. Twenty cores (extracted with a no. 4 cork borer [diameter, $8.75 \mathrm{~mm}$ ] and with the deeper, orange-red undermat layers removed) were taken from a slow-flowing side channel at a temperature of $60^{\circ} \mathrm{C}$ at 0530 (predawn) on 19 June 2009. Cores were separated into four vials (five cores per vial), and $5 \mathrm{ml}$ of the incubation solutions was added to the cores (two vials with ${ }^{12} \mathrm{C}$ and two vials with ${ }^{13} \mathrm{C}$; see above) at 0550 . The sample incubations were initiated at 0601 in a small pool where the measured temperature was $63^{\circ} \mathrm{C}$. This pool was in the shadow cast by an adjacent hillside throughout the incubation period. Visible irradiance $(400$ to $700 \mathrm{~nm})$ was monitored with an LI-192 irradiance sensor (Li-Cor, Lincoln, NE, USA). Incubations were stopped by freezing samples on dry ice at 0900, the time when sunlight began to illuminate the incubation area directly.

Protein extraction. Core samples incubated with ${ }^{12} \mathrm{C}$-labeled buffer were combined, core samples incubated with ${ }^{13} \mathrm{C}$-labeled buffer were combined, and the two sample sets were subsequently treated identically. Cores were lyophilized, and approximately $0.05 \mathrm{~g}$ of the crushed core material was placed into $1.5 \mathrm{ml}$ of a buffer consisting of $0.1 \mathrm{M}$ triethylammonium bicarbonate (TEAB), $0.1 \%$ Triton $\mathrm{X}-100$, and $6 \mathrm{M}$ guanidine, $\mathrm{pH}$ 8.5, containing one Roche miniprotease inhibitor tablet per $10 \mathrm{ml}$. Samples were then subjected to bead beating for two bursts lasting $30 \mathrm{~s}$ in a Mini-BeadBeater 8 (Biospec Products, Bartlesville, OK) (with maximum homogenization at 3,200 oscillations per min using $1 \mathrm{ml}$ of 425- to $600-\mu \mathrm{m}$ acid-washed glass beads [Sigma, St. Louis, MO]). Homogenates were centrifuged at 11,000 $\times g$ for $10 \mathrm{~min}$ to pellet insoluble material. Proteins from the resulting supernatants were precipitated with 5 volumes of $0.1 \mathrm{M}$ ammonium acetate in $100 \%$ methanol overnight at $-20^{\circ} \mathrm{C}$. Samples were centrifuged for $10 \mathrm{~min}$ at $800 \times g$ at $4^{\circ} \mathrm{C}$, and the protein pellets were washed once in $0.08 \mathrm{M}$ ammonium acetate in $80 \%(\mathrm{vol} / \mathrm{vol})$ aqueous methanol. After centrifugation, the pellets were washed in $80 \%$ (vol/vol) aqueous acetone. Pellets were resuspended in a minimal volume (20 to $500 \mu \mathrm{l})$ of $5 \mathrm{mM}$ TEAB, $8 \mathrm{M}$ urea, $2 \%$ (wt/vol) Triton X-100, and $0.1 \%$ sodium dodecyl sulfate (SDS), $\mathrm{pH} 8.5$, and an aliquot was subjected to amino acid analysis to determine the protein concentration.

Trypsin digestion. Briefly, $250 \mu \mathrm{g}$ of protein (in $40 \mu \mathrm{l}$ ) was reduced by treatment for $1 \mathrm{~h}$ at room temperature with $50 \mathrm{mM}$ tris(2-carboxyethyl)-phosphine (1 $\mathrm{mM}$ final concentration), and the cysteines were blocked by treatment for $10 \mathrm{~min}$ at room temperature with $200 \mathrm{mM}$ methylmethane-thiosulfonate ( $0.125 \mathrm{mM}$ final concentration). These samples were then diluted 1:10 by addition of $360 \mu \mathrm{l}$ of $50 \mathrm{mM}$ TEAB, pH 8.5, and $25 \mu \mathrm{g}$ of TPCK (L-1-tosylamido-2-phenylethyl chloromethyl ketone)-treated trypsin 
(Applied Biosystems, Foster City, CA) was added to each sample. An additional aliquot of trypsin (5 $\mu \mathrm{g}$ ) was added to the samples after $2.5 \mathrm{~h}$ of incubation; the samples were incubated overnight at $37^{\circ} \mathrm{C}$ and then dried under vacuum.

Strong cation exchange chromatography. Trypsinized samples were resuspended in $10 \mathrm{mM}$ $\mathrm{KH}_{2} \mathrm{PO}_{4}(250 \mu \mathrm{l})$ containing $25 \%$ (vol/vol) acetonitrile, $\mathrm{pH} 3$ (buffer A), and the $\mathrm{pH}$ was adjusted to 2.7 to 3 with $85 \%$ ( $\mathrm{vol} / \mathrm{vol}$ ) phosphoric acid. Each sample was loaded onto a PolySulfoethyl A SCX column (100 by $4.6 \mathrm{~mm}$; inside diameter, $5 \mu \mathrm{m}$; particle size, $300 \AA$ [PolyLC Inc, Columbia, MD]) and analyzed using a Magic 2002 high-performance liquid chromatograph (HPLC; Michrom Biosciences, Inc., Auburn, CA). The elution gradient was $135 \mathrm{~min}\left(200 \mu \mathrm{min}^{-1}\right)$ and consisted of $0 \%$ buffer B (buffer B is buffer A with $500 \mathrm{mM} \mathrm{KCl}, \mathrm{pH} 3.0$ ) for $45 \mathrm{~min}, 0 \%$ to $12 \%$ B for $15 \mathrm{~min}, 12 \%$ B to $50 \%$ B for $45 \mathrm{~min}, 50 \%$ B to $100 \%$ B for $15 \mathrm{~min}$, and then $100 \%$ B for $15 \mathrm{~min}$. Fractions (200 $\mu \mathrm{l}$ per fraction) were taken at 1-min intervals; most peptides eluted between 60 and $105 \mathrm{~min}$. Fractions containing peptides were dried and resuspended in $50 \mu \mathrm{l}$ of $2 \%$ ( $\mathrm{vol} / \mathrm{vol})$ acetonitrile- $0.1 \%$ ( $\mathrm{vol} / \mathrm{vol})$ formic acid.

Mass spectral analysis. Individual fractions from the 45 fractions that contained the majority of the peptides from mat samples incubated with ${ }^{12} \mathrm{C}$ - or ${ }^{13} \mathrm{C}$-labeled bicarbonate solutions were subjected to capillary LC-MS/MS analysis using a linear trap quadrupole (LTQ)-Orbitrap Velos mass spectrometer (ThermoFinnigan, Somerset, NJ). For details concerning the MS analysis, see Slysz et al. (5).

Data analysis. Raw data from the LTQ-Orbitrap Velos instrument were first processed by DeconMSn (46) to determine the monoisotopic mass and charge state of precursor ions accurately; this was followed by SEQUEST searching (3-Da tolerance for parent ion; 1-Da tolerance for fragments; no enzyme defined; no modifications defined) of the MS/MS data against the translated and annotated metagenome from Mushroom Spring and Octopus Spring (22). SEQUEST results for all data sets were rescored using MS-GF $(47,48)$, and peptides with an MS-GF spectral probability of less than $4 \times 10^{-10}$ (false-discovery rate of $1 \%)$ were included in a reference peptide database for subsequent use in data analysis (49). For each data set, LC-MS/MS mass and normalized elution time features were extracted using DeconTools $(50,51)$ and VIPER (52) and matched to peptides in the reference database. False-discovery rates of the identification process were estimated using STAC as previously described (53).

Data sets were subjected to analysis by SIPPER (5) to determine the presence of ${ }^{13} \mathrm{C}$ labeling in the peptides. SIPPER determination of peptide labeling was made using the "tight" filter, which returns a false-positive rate of $5 \%$ to $10 \%$ (see reference 5 for a full discussion of the factors influencing label incorporation). The SIPPER determination of labeling was correlated with the refence peptide database (as determined by MS-GF; see above). The determination of the taxonomic sources and predicted functions of the proteins from the translated, annotated metagenome were updated using NCBI BLAST with the $\mathrm{NCBI}$ nonredundant (nr) database and a custom database representing taxocene clusters detected by Klatt et al. (22) (see Data Set S2 in the supplemental material). We determined the peptides that appeared uniquely in one of the eight taxa listed in Table 1 (or were unique but did not fit into one of these taxa) and used the number of unique-to-taxon peptides for all quantitation except where specifically noted otherwise.

Bulk ${ }^{13} \mathrm{C}$ measurement. Bulk isotope analysis was used to verify incorporation of ${ }^{13} C_{i}$ into the proteins extracted from mat samples. Briefly, we used a Costech ECS 4010 CHNSO elemental analyzer (Costech, Valencia, CA) coupled to a Thermo Scientific (Bremen, Germany) Delta V Plus isotope ratio mass spectrometer. Samples were loaded into tin capsules for introduction to the elemental analyzer, where sample combustion was performed using a reactor (maintained at $1,020^{\circ} \mathrm{C}$ ) loaded with cobaltic oxide and chromium oxide catalyst, and subsequent reduction was performed by a reactor filled with copper catalyst and maintained at $650^{\circ} \mathrm{C}$. In-house glutamic acid standards ( $\delta^{13} \mathrm{C}$ of $16.73 \%$ and $-11.09 \%$ ) were calibrated against U.S. Geological Survey (USGS) 40 and USGS 41 standards (54) (applied $\delta^{13} \mathrm{C}$ values of $-26.39 \%$ and $+37.63 \%$, respectively) and used as a basis for a two-point data correction (55). We report all bulk isotope content in standard delta $(\delta)$ notation as follows: $\delta=\left(R_{\text {sample }} / R_{\text {standard }}-1\right) \times 1,000$, where $R_{\text {sample }}$ is the measured ${ }^{13} \mathrm{C} /{ }^{12} \mathrm{C}$ ratio of a sample, and $R_{\text {standard }}$ is that of a standard. In this case we reference all isotope measurements to Vienna Pee Dee Belemnite (VPDB) with an $R_{\text {standard }}$ of 0.0112372 .

\section{SUPPLEMENTAL MATERIAL}

Supplemental material is available online only.

SUPPLEMENTAL FILE 1, XLSX file, $2.4 \mathrm{MB}$.

SUPPLEMENTAL FILE 2, XLSX file, $0.5 \mathrm{MB}$.

\section{ACKNOWLEDGMENTS}

This research was supported by the Genomic Science Program, Office of Biological and Environmental Research (OBER), U.S. Department of Energy, and is a contribution of the Pacific Northwest National Laboratory Foundational Scientific Focus Area. Work was performed in the Environmental Molecular Science Laboratory, a U.S. Department of Energy (DOE) national scientific user facility at Pacific Northwest National Laboratory (PNNL) in Richland, WA. L.S. and D.M.W. acknowledge support by the National Science Foundation (EF 0805385). D.M.W. also acknowledges support from the NASA Exobiology Program (NAG5-8824, NAG5-13468, NNX09AM87G, and NNX16AJ62G), the NSF IGERT program (DGE 0654336), and the Montana Agricultural Experiment Station project 911352. D.A.B. acknowledges support from the NASA Exobiology Program 
(NNX16AJ62G) and the U.S. Department of Energy (DE-FG02-94ER20137). Portions of this research were enabled by the DOE/OBER under the Pan-omics project and were performed in the Environmental Molecular Science Laboratory, a U.S. Department of Energy national scientific user facility at Pacific Northwest National Laboratory in Richland, WA. Battelle operates PNNL for the DOE under contract DE-AC0576RLO01830. The University of Nebraska Medical Center (UNMC) Protein Structure Core Facility, supported by the Nebraska Research Initiative, was instrumental in the completion of this work.

We appreciate the assistance of Tracy Cheever during the field expedition, Pauline Zheng for aid in data analysis, and the technical assistance of Michele Fontaine. This study was conducted under Yellowstone National Park permits YELL-0129 (D.M.W.) and YELL-0567 (L.S.). We gratefully acknowledge the support and assistance of National Park Service personnel at Yellowstone National Park.

\section{REFERENCES}

1. Staley JT, Castenholz RW, Colwell RR, Hold JG, Kane MD, Pace NR, Salyers AA, Tiedje JM. 1997. The microbial world: foundation of the biosphere. American Academy of Microbiology, Washington, DC.

2. Jehmlich $\mathrm{N}$, Schmidt F, Hartwich $\mathrm{M}$, von Bergen $\mathrm{M}$, Richnow $\mathrm{H}-\mathrm{H}$, Vogt $\mathrm{C}$. 2008. Incorporation of carbon and nitrogen atoms into proteins measured by protein-based stable isotope probing (protein-SIP). Rapid Commun Mass Spectrom 22:2889-2897. https://doi.org/10.1002/rcm.3684.

3. Jehmlich N, Vogt C, Lünsmann V, Richnow HH, von Bergen M. 2016. Protein-SIP in environmental studies. Curr Opin Biotechnol 41:26-33. https://doi.org/10.1016/j.copbio.2016.04.010.

4. Pan C, Fischer CR, Hyatt D, Bowen BP, Hettich RL, Banfield JF. 2011. Quantitative tracking of isotope flows in proteomes of microbial communities. Mol Cell Proteomics 10:M110.006049. https://doi.org/10.1074/ mcp.M110.006049.

5. Slysz G, Steinke L, Ward D, Klatt C, Clauss T, Purvine S, Payne S, Anderson G, Smith R, Lipton M. 2014. Automated data extraction from in situ protein stable-isotope probing studies. J Proteome Res 13:1200-1210. https://doi.org/10.1021/pr400633j.

6. Lünsmann V, Kappelmeyer W, Benndorf R, Martinez-Lavanchy PM, Taubert A, Adrian L, Duarte M, Pieper DH, von Bergen M, Müller JA, Heipieper HJ, Jehmlich N. 2016. In situ protein-SIP highlights Burkholderiaceae as key players degrading toluene by para ring hydroxylation in a constructed wetland model. Environ Microbiol 18:1176-1186. https:// doi.org/10.1111/1462-2920.13133.

7. Mosbæk F, Kjeldal H, Mulat DG, Albertsen M, Ward AJ, Feilberg A, Nielsen JL. 2016. Identification of syntrophic acetate-oxidizing bacteria in anaerobic digesters by combined protein-based stable isotope probing and metagenomics. ISME J 10:2405-2418. https://doi.org/10.1038/ismej .2016 .39 .

8. Starke R, Keller A, Jehmlich N, Vogt C, Richnow HH, Kleinsteuber S, von Bergen M, Seifert J. 2016. Pulsed ${ }^{13} C_{2}$-acetate protein-SIP unveils Epsilonproteobacteria as dominant acetate utilizers in a sulfate-reducing microbial community mineralizing benzene. Microb Ecol 71:901-911. https://doi.org/10.1007/s00248-016-0731-y.

9. Marlow JJ, Skennerton CT, Li Z, Chourey K, Hettich RL, Pan C, Orphan VJ. 2016. Proteomic stable isotope probing reveals biosynthesis dynamics of slow growing methane based microbial communities. Front Microbiol 7:563. https://doi.org/10.3389/fmicb.2016.00563.

10. Ward DM, Bauld J, Castenholz RW, Pierson BK. 1992. Modern phototrophic microbial mats: anoxygenic, intermittently oxygenic/ anoxygenic, thermal, eucaryotic and terrestrial, p 309-324. In Schopf JW, Klein C (ed), The proterozoic biosphere: a multidisciplinary study. Cambridge University Press, Cambridge, United Kingdom.

11. Ward DM, Castenholz RW, Miller SR. 2012. Cyanobacteria in geothermal habitats, p 39-63. In Whitton BA (ed), Ecology of cyanobacteria, 2nd ed. Springer, Heidelberg, Germany.

12. Ward DM, Klatt CG, Wood J, Cohan FM, Bryant DA. 2012. Functional genomics in an ecological and evolutionary context: maximizing the value of genomes in systems biology, p 1-16. In Burnap RL, Vermaas W (ed), Functional genomics and evolution of photosynthetic systems. Springer, Dordrecht, The Netherlands.

13. Brock TD. 1978. Thermophilic microorganisms and life at high temperature. Springer-Verlag, New York, NY.
14. Hanada S, Takaichi S, Matsuura K, Nakamura K. 2002. Roseiflexus castenholzii gen. nov., sp. nov., a thermophilic, filamentous, photosynthetic bacterium that lacks chlorosomes. Intl J System Evol Biol 52:187-192. https://doi.org/10.1099/00207713-52-1-187.

15. Anderson KL, Tayne TA, Ward DM. 1987. Formation and fate of fermentation products in hot spring cyanobacterial mats. Appl Environ Microbiol 53:2343-2352. https://doi.org/10.1128/AEM.53.10.2343-2352.1987.

16. Bateson MM, Ward DM. 1988. Photoexcretion and consumption of glycolate in a hot spring cyanobacterial mat. Appl Environ Microbiol 54:1738-1743. https://doi.org/10.1128/AEM.54.7.1738-1743.1988.

17. Holo $\mathrm{H}$, Sirevåg R. 1986. Autotrophic growth and $\mathrm{CO}_{2}$ fixation of Chloroflexus aurantiacus. Arch Microbiol 145:173-180. https://doi.org/10 .1007/BF00446776.

18. van der Meer MTJ, Schouten S, de Leeuw JW, Ward DM. 2000. Autotrophy of green non-sulphur bacteria in hot spring microbial mats: biological explanations for isotopically heavy organic carbon in the geological record. Environ Microbiol 2:428-435. https://doi.org/10.1046/j.1462 $-2920.2000 .00124 . x$.

19. van der Meer MTJ, Schouten S, Damsté JSS, de Leeuw JW, Ward DM. 2003. Compound-specific isotopic fractionation patterns suggest different carbon metabolisms among Chloroflexus-like bacteria in hot spring microbial mats. Appl Environ Microbiol 69:6000-6006. https://doi.org/ 10.1128/aem.69.10.6000-6006.2003.

20. van der Meer MT, Schouten S, Bateson MM, Nübel U, Wieland A, Kühl M, de Leeuw JW, Sinninghe-Damsté JS, Ward DM. 2005. Diel variations in carbon metabolism by green nonsulfur-like bacteria in alkaline siliceous hot spring microbial mats from Yellowstone National Park. Appl Environ Microbiol 71:3978-3986. https://doi.org/10.1128/AEM.71.7.3978-3986 .2005 .

21. van der Meer MT, Schouten S, Sinninghe-Damsté JS, Ward DM. 2007. Impact of carbon metabolism on ${ }^{13} \mathrm{C}$ signatures of cyanobacteria and green non-sulfur-like bacteria inhabiting a microbial mat from an alkaline siliceous hot spring in Yellowstone National Park (USA). Environ Microbiol 9:482-491. https://doi.org/10.1111/j.1462-2920.2006.01165.x.

22. Klatt CG, Wood JM, Rusch DB, Bateson MM, Hamamura N, Heidelberg JF, Grossman AR, Bhaya D, Cohan FM, Kühl M, Bryant DA, Ward DM. 2011. Community ecology of hot spring cyanobacterial mats: predominant populations and their functional potential. ISME J 5:1262-1278. https:// doi.org/10.1038/ismej.2011.73

23. Thiel V, Hügler M, Ward DM, Bryant DA. 2017. The dark side of the Mushroom Spring microbial mat: life in the shadow of chlorophototrophs. II. Metabolic functions of abundant community members predicted from metagenomic analyses. Front Microbiol 8:943. https://doi .org/10.3389/fmicb.2017.00943.

24. Thiel V, Wood JM, Olsen MT, Ward DM, Bryant DA. 2016. The dark side of the Mushroom Spring microbial mat: life in the shadow of chlorophototrophs. I. Microbial diversity based on 16S rRNA amplicon and metagenome sequencing. Front Microbiol 7:919. https://doi.org/10 .3389/fmicb.2016.00919.

25. Tank M, Thiel V, Ward DM, Bryant DA. 2017. A panoply of phototrophs: a photomicrographic overview of the thermophilic chlorophototrophs of the microbial mats of alkaline siliceous hot springs in Yellowstone National Park, WY, USA, p 87-137. In Hallenbeck PC (ed), Modern topics 
in the phototrophic prokaryotes: environmental and applied aspects. Springer, Berlin, Germany.

26. Thiel V, Tank M, Bryant DA. 2018. Diversity of chlorophototrophic bacteria revealed in the omics era. Annu Rev Plant Biol 69:21-49. https:// doi.org/10.1146/annurev-arplant-042817-040500.

27. Bryant DA, Garcia Costas AM, Maresca JA, Gomez Maqueo Chew A, Klatt CG, Bateson MM, Tallon LJ, Hostetler J, Nelson WC, Heidelberg JF, Ward DM. 2007. Candidatus Chloracidobacterium thermophilum: an aerobic phototrophic acidobacterium. Science 317:523-526. https://doi.org/10 $.1126 /$ science. 1143236.

28. Tank M, Bryant DA. 2015. Nutrient requirements and growth physiology of the photoheterotrophic Acidobacterium, Chloracidobacterium thermophilum. Front Microbiol 6:226. https://doi.org/10.3389/fmicb.2015 .00226 .

29. Tank M, Bryant DA. 2015. Chloracidobacterium thermophilum gen. nov., sp. nov.: an anoxygenic microaerophilic chlorophotoheterotrophic acidobacterium. Int J Syst Evol Microbiol 65:1426-1430. https://doi.org/10 $.1099 /$ ijs.0.000113.

30. Tank M, Garcia Costas AM, Bryant DA. 12 December 2018. Chloracidobacterium. In Whitman WB, Rainey F, Kampfer P, Trujillo M, Chun J, DeVos P, Hedlund B, Dedysh S (ed), Bergey's manual of systematics of Bacteria and Archaea. John Wiley \& Sons, New York, NY. https://doi.org/ 10.1002/9781118960608.gbm01534.

31. Liu Z, Klatt CG, Ludwig M, Rusch DB, Jensen SI, Kühl M, Ward DM, Bryant DA. 2012. "Candidatus Thermochlorobacter aerophilum": an aerobic chlorophotoheterotrophic member of the phylum Chlorobi defined by metagenomics and metatranscriptomics. ISME J 6:1869-1882. https:// doi.org/10.1038/ismej.2012.24.

32. Bryant DA, Klatt CG, Frigaard N-U, Liu Z, Li T, Zhao F, Garcia Costas AM, Overmann J, Ward DM. 2012. Comparative and functional genomics of anoxygenic green bacteria from the taxa Chlorobi, Chloroflexi, and Acidobacteria, p 47-102. In Burnap RL, Vermaas W (ed), Functional genomics and evolution of photosynthetic systems. Springer, Dordrecht, The Netherlands.

33. Schaffert CS, Klatt CG, Ward DM, Pauley M, Steinke LA. 2012. Identification and distribution of high-abundance proteins in the Octopus Spring microbial mat community. Appl Environ Microbiol 78:8481-8484. https://doi.org/10.1128/AEM.01695-12.

34. Liu Z, Klatt CG, Wood JM, Rusch DB, Ludwig M, Wittekindt N, Tomsho LP, Schuster SC, Ward DM, Bryant DA. 2011. Metatranscriptomic analyses of chlorophototrophs of a hot spring microbial mat. ISME J 5:1279-1290. https://doi.org/10.1038/ismej.2011.37.

35. Nübel U, Bateson MM, Vandieken V, Wieland A, Kühl M, Ward DM. 2002. Microscopic examination of distribution and phenotypic properties of phylogenetically diverse Chloroflexaceae-related bacteria in hot spring microbial mats. Appl Environ Microbiol 68:4593-4603. https://doi.org/ 10.1128/aem.68.9.4593-4603.2002.

36. Steunou A-S, Bhaya D, Bateson MM, Melendrez MC, Ward DM, Brecht $E_{,}$ Peters JW, Kühl M, Grossman AR. 2006. In situ analysis of nitrogen fixation and metabolic switching in unicellular thermophilic cyanobacteria inhabiting hot spring microbial mats. Proc Natl Acad Sci U S A 103:2398-2403. https://doi.org/10.1073/pnas.0507513103.

37. Steunou A-S, Jensen SI, Brecht E, Becraft ED, Bateson MM, Kilian O, Bhaya D, Ward DM, Peters JW, Grossman AR, Kühl M. 2008. Regulation of nif gene expression and the energetics of $\mathrm{N}_{2}$ fixation over the diel cycle in a hot spring microbial mat. ISME J 2:364-378. https://doi.org/10.1038/ ismej.2007.117.

38. Klatt CG, Liu Z, Ludwig M, Kühl M, Jensen SI, Bryant DA, Ward DM. 2013. Temporal metatranscriptomic patterning in phototrophic Chloroflexi inhabiting a microbial mat in a geothermal spring. ISME J 7:1775-1789. https://doi.org/10.1038/ismej.2013.52.

39. Nold SC, Ward DM. 1996. Photosynthate partitioning and fermentation in hot spring microbial mat communities. Appl Environ Microbiol 62: 4598-4607. https://doi.org/10.1128/AEM.62.12.4598-4607.1996.

40. Kim Y-M, Nowack S, Olsen MT, Becraft ED, Wood JM, Thiel V, Klapper I, Kühl M, Fredrickson JK, Bryant DA, Ward DM, Metz TO. 2015. Diel metabolomics analysis of a hot spring chlorophototrophic microbial mat leads to new hypotheses of community member metabolisms. Front Microbiol 6:209. https://doi.org/10.3389/fmicb.2015.00209.

41. Dillon JG, Fishbain S, Miller SR, Bebout BM, Habicht KS, Webb SM, Stahl DA. 2007. High rates of sulfate reduction in a low-sulfate hot spring microbial mat are driven by a low level of diversity of sulfate-respiring microorganisms. Appl Environ Microbiol 73:5218-5226. https://doi.org/ 10.1128/AEM.00357-07.

42. Revsbech NP, Trampe E, Lichtenberg N, Ward DMm, Kuhl M. 2016. In situ hydrogen dynamics in a hot spring microbial mat during a diel cycle. Appl Environ Microbiol 82:4209-4217. https://doi.org/10.1128/AEM .00710-16.

43. Fuchs G. 2011. Alternative pathways of carbon dioxide fixation: insights into the early evolution of life. Annu Rev Microbiol 65:631-658. https:// doi.org/10.1146/annurev-micro-090110-102801.

44. van der Meer MT, Schouten S, van Dongen BE, Rijpstra WI, Fuchs G, Damste JS, de Leeuw JW, Ward DM. 2001. Biosynthetic controls on the ${ }^{13} \mathrm{C}$-contents of organic components in the photoautotrophic bacterium Chloroflexus aurantiacus. J Biol Chem 276:10971-10976. https://doi.org/ 10.1074/jbc.M009701200.

45. Jensen Sl, Steunou A-S, Bhaya D, Kühl M, Grossman AR. 2011. In situ dynamics of $\mathrm{O}_{2}, \mathrm{pH}$ and cyanobacterial transcripts associated with CCM, photosynthesis and detoxification of ROS. ISME J 5:317-328. https://do .org/10.1038/ismej.2010.131.

46. Mayampurath AM, Jaitly N, Purvine SO, Monroe ME, Auberry KJ, Adkins JN, Smith RD. 2008. DeconMSn: a software tool for accurate parent ion monoisotopic mass determination for tandem mass spectra. Bioinformatics 24:1021-1023. https://doi.org/10.1093/bioinformatics/btn063.

47. Kim S, Mischerikow N, Bandeira N, Navarro JD, Wich L, Mohammed S, Heck AJR, Pevzner PA. 2010. The generating function of CID, ETD, and CID/ETD pairs of tandem mass spectra: applications to database search. Mol Cell Proteomics 9:2840-2852. https://doi.org/10.1074/mcp.M110 .003731.

48. Kim S, Pevzner PA. 2014. MS-GF+: universal database search tool for mass spectrometry. Nat Commun 5:5277. https://doi.org/10.1038/ ncomms6277.

49. Zimmer JSD, Monroe ME, Qian WJ, Smith RD. 2006. Advances in proteomics data analysis and display using an accurate mass and time tag approach. Mass Spectrom Rev 25:450-482. https://doi.org/10.1002/mas .20071.

50. Jaitly N, Mayampurath A, Littlefield K, Adkins JN, Anderson GA, Smith RD. 2009. Decon2LS: an open-source software package for automated processing and visualization of high resolution mass spectrometry data. BMC Bioinformatics 10:87-2666663. https://doi.org/10.1186/1471-2105 $-10-87$.

51. Slysz GW, Baker ES, Shah AR, Jaitly N, Anderson GA, Smith RD. 2010. The DeconTools framework: an application programming interface enabling flexibility in accurate mass and time tag workflows for proteomics and metabolomics, poster TP033. 58th ASMS Conf Mass Spectrom Allied Topics, Salt Lake City, Utah, 23 to 27 May 2010.

52. Monroe ME, Tolic N, Jaitly N, Shaw JL, Adkins JN, Smith RD. 2007. VIPER: an advanced software package to support high-throughput LC-MS peptide identification. Bioinformatics 23:2021-2023. https://doi.org/10 .1093/bioinformatics/btm281.

53. Stanley JR, Adkins JN, Slysz GW, Monroe ME, Purvine SO, Karpievitch YV, Anderson GA, Smith RD, Dabney AR. 2011. A statistical method for assessing peptide identification confidence in accurate mass and time tag proteomics. Anal Chem 83:6135-6140. https://doi.org/10.1021/ ac2009806.

54. Qi H, Coplen TB, Geilmann H, Brand WA, Böhlke JK. 2003. Two new organic reference materials for the $\delta^{13} \mathrm{C}$ and $\delta^{15} \mathrm{~N}$ measurements and a new value for the $\delta 13 \mathrm{C}$ of NBS 22 oil. Rapid Commun Mass Spectrom 17:2483-2487. https://doi.org/10.1002/rcm.1219.

55. Coplen TB, Brand WA, Gehre M, Gröning M, Meijer HAJ, Toman B, Verkouteren RM. 2006. New guidelines for $\delta^{13} \mathrm{C}$ measurements. Anal Chem 78:2439-2441. https://doi.org/10.1021/ac052027c. 